\title{
HUBUNGAN ANTARA POLA ASUH ORANG TUA DENGAN KEMAMPUAN MEAN LENGTH OF UTTERANCE (MLU) PADA ANAK USIA PRA SEKOLAH
}

\author{
Sudarman, Roy Romey Daulas M, Muryanti \\ Kementerian Kesehatan Politeknik Kesehatan Surakarta Jurusan Terapi Wicara
}

\begin{abstract}
Parenting Parenting Patterns, Ability Mean Length Of Utterance (MLU), Pre School Children. Parents are the main teachers who can help their children to learn science in everyday life. Scientific in everyday life except influenced by education in school and parenting pattern at home and environment. The pattern of foster habits is a representation of attitudes and behaviors in and speaking, communicating during parenting activities. In the early stages the child uses a one-word sentence, two-word sentence, three-word sentence, and so on until the complete sentence of the structure. The number of elements that contain meaning in the sentence can be expressed with Mean Length of Tough (MLU). MLU is a concept used to measure linguistic products produced by a child. The general objective of this research is to know the relationship between parents' parenting patterns with the ability of Mean Length Recognition (MLU) in preschool children in Kindergarten ABA Toyibah Surakarta and TK Sri Juwita Hanum Surakarta. The type of this research is quantitative research with analytic observational design with cross sectional approach, in this research there is no intervention/ respondent to the respondent, and only one time and do not follow up. This research will be done at TKABA Toyibah and TK Sri Juwita Hanum Surakarta by using purposive sampling technique. From result of statistical analysis using "Kendall's_tau" analysis on parenting parenting variable with MLU ability in both kindergarten that is TK ABA Thoyibah and TK Sri Juwita Hanum Surakarta obtained p value 0,000, which means $p$ value $0.000 \leq 0,05$, This shows that there is a significant parenting pattern between parents with the ability of MLU in TK ABA Thoyibah and kindergarten Sri Juwita Hanum Surakarta. The direction can be seen from the value of 0.364 rhitung which means there is a positive parenting with parents with the ability of MLU in kindergarten Sri Juwita Hanum Surakarta. While the references of the results rhitung 0.364, which shows the retreat power including "weak" because it is included in between 0.20-0.399.
\end{abstract}

Keywords : Parenting Parenting Patterns, Ability Mean Length Of Utterance (MLU), Pre School Children

Abstrak : Pola Asuh Orang Tua, Kemampuan Mean Length Of Utterance (MLU), Anak Usia Pra Sekolah. Keluarga khususnya orangtua memegang peranan yang sangat penting karena orang tua adalah guru utama yang dapat membawa anak-anak mereka untuk memperoleh ilmu dalam kehidupan sehari-hari. Keilmuan dalam kehidupan sehari-harai selain di pengaruahi oleh pendidikan disekolah dan pola asuh orang tua di rumah dan lingkungan. Pola asuh orangtua merupakan gambaran tentang sikap dan perilaku orangtua dan anak dalam berinteraksi, berkomunikasi selama mengadakan kegiatan pengasuhan. Pada periode awal anak menggunakan kalimat satu kata, kalimat 
dua kata, kalimat tiga kata, dan seterusnya sampai tahap kalimat lengkap strukturnya. Jumlah elemen yang mengandung arti dalam kalimat yang diucapkan anak dapat dapat diukur dengan Mean Length of Utterance (MLU). MLU merupakan satu konsep yang digunakan untuk mengukur produk linguistik yang dihasilkan oleh seseorang anak. Tujuan umum dalam penelitian ini adalah untuk mengetahui hubungan antara pola asuh orang tua dengan kemampuan Mean Length of Utterance (MLU) pada anak usia prasekolah di TK ABA Toyibah Surakarta dan TK Sri Juwita Hanum Surakarta. Jenis penelitian ini adalah penelitian kuantitatif dengan rancangan analitic observational melalui pendekatan potong lintang (Cross Sectional), dalam penelitian ini tidak terdapat intervensi/perlakuan terhadap responden, dan hanya di observasi satu kali saja dan tidak melakukan tindak lanjut. Penelitian ini akan dilakukan di TKABA Toyibah dan TK Sri Juwita Hanum Surakarta dengan menggunakan teknik purposive sampling. Dari hasil uji statistik korelasi dengan menggunakan analisis "Kendall's_tau" pada variabel pola asuh orang tua dengan kemampuan MLU di kedua TK yaitu TK ABA Thoyibah dan TK Sri Juwita Hanum Surakarta diperoleh nilai $p$ value 0.000 , yang berarti nilai $p$ value $0.000 \leq$ 0.05 , hal ini menunjukan ada hubunganyang signifikan antara pola asuh orang tua dengan kemampuan MLU di TK ABA Thoyibah dan TK Sri Juwita Hanum Surakarta. Adapun arah korelasi dapat dilihat dari nilai rhitung 0.364 yang berarti ada korelasi yang positif antara Pola asuh orang tua dengan kemampuan MLU di TK Sri Juwita Hanum Surakarta. Sedangkan kekuatan hubungan dapat dilihat dari hasil nilai rhitung 0.364, yang menunjukan kekuatan korelasi termasuk "lemah" karena termasuk diantara 0.20-0.399.

Kata Kunci : Pola Asuh Orang Tua, Kemampuan Mean Length Of Utterance (MLU), Anak Usia Pra Sekolah

\section{PENDAHULUAN}

Keluarga khususnya orang tua memegang peranan yang sangat penting dalam perkembagan bahasa dan bicara anak, karena orang tua adalah guru utama yang dapat membawa anak-anak mereka untuk memperoleh pengetahuan dan pengalaman dalam kehidupan sehari-hari. Keilmuan/pengetahuan dan pengalaman dalam kehidupan sehari-hari selain di pengaruhi oleh pendidikan disekolah juga dipengaruhi oleh pola asuh orang tua di rumah dan lingkungan. Menurut Maccoby (1980) pola asuh orang tua merupakan penggambaran interaksi orang tua dan anak-anak yang di dalamnya orang tua mengekspresikan sikap-sikap atau perilaku, nilai-nilai, minat dan harapanharapannya dalam mengasuh dan memenuhi kebutuhan anak-anaknya. Hal ini sejalan dengan pendapat Euis (2004) "Pola asuh merupakan serangkaian interaksi yang intensif, orangtua mengarahkan anak untuk memiliki kecakapan hidup. Ada berbagai macam pola asuh yang dapat diterapkan orang tuadalam mendidik anaknya.

Menurut Stewart dan Koch (1983), mengelompokan jenis pola asuh meliputi pola asuh otoriter, demokratis dan permisif. Pola asuh otoriter memiliki ciri antara lain: kaku, tegas, suka menghukum, kurang adanya kasih sayang dan rasa simpatik. Berdasarkan ketiga karakteristik pola asuh orang tua yang berbeda beda tersebut, penting bagi orang tua untuk dapat memahami mana pola asuh yang tepat yang nantinya akan berdampak baik 
bagi perkembangan bahasa dan bicara sianak. Jadi pola asuh orang tua adalah suatu keseluruhan interaksi antara orang tua dengan anak, di mana orang tua bermaksud menstimulasi anaknya dengan mengubah tingkah laku, pengetahuan serta nilai-nilai yang dianggap paling tepat oleh orang tua, agar anak dapat mandiri, tumbuh dan berkembang secara sehat dan optimal baik pada kemampuan kognitif maupun kemampuan bahasa dan bicara.

Bahasa merupakan salah satu aspek penting dalam kehidupan manusia. Bahasa juga memegang peranan penting dalam kehidupan sosial. Perkembangan bahasa terkadang juga dianggap sebagai salah satu indikator dari perkembangan dan kemampuan kognitif pada anak-anak, oleh karena itu bahasa erat hubungannya dengan pencapaian prestasi di sekolah. Bahasa dapat membantu seseorang atau kelompok untuk berinteraksi dan saling bertukar informasi. Seseorang dapat berkomunikasi dengan baik apabila kemampuan bahasanya juga baik, sebaliknya seseorang tidak dapat berkomunikasi dengan baik apabila kemampuan bahasanya tidak baik

Salah satu perkembangan bahasa yang khas dialami anak adalah perkembangan sintaksis. Pada periode awal anak menggunakan kalimat satu kata, kalimat dua kata, kalimat tiga kata, dan seterusnya sampai tahap kalimat lengkap strukturnya (agent-action-object location). Jumlah elemen yang mengandung arti dalam kalimat yang diucapkan anak dapat dapat diukur dengan Mean Length of Utterance $(M L U)$. MLU merupakan satu konsep yang digunakan untuk mengukur produk linguistik yang dihasilkan oleh seseorang anak. Secara umum, penghitungan $M L U$ dilakukan dengan membagi bilangan morfem dengan bilangan ujaran. Artinya, jumlah bilangan ujaran yang diperlukan ialah 50 atau 100 ujaran utama anak. Semakin tinggi $M L U$ anak maka semakin tinggilah penguasaan berbahasa anak tersebut.

Salah satu indikator perkembangan bahasa ditandai dengan peningkatan panjang rata-rata ujaran yang diukur dalam morfem. Brown (1973), memperkenalkan MLU (Mean Length Utterance) dalam morfem, selanjutnya MLU digunakan oleh peneliti bahasa anak dan terapis wicara sebagai suatu cara untuk mengukur perkembangan bahasa. MLU digunkan sebagai dasar untuk memprediksi sejauh mana perkembangan bahasa yang dimiliki oleh anak. Setelah Brown (1973) dan peneliti lain melakukan perhitungan MLU untuk mengukur korelasi perkembangan morfologi dan kemampuan sintaksis pada anak, perhitungan MLU menjadi semakin diterima dan semakin luas. MLU dapat digunakan secara efektif untuk mengukur perkembangan bahasa kasar pada anak.

MLU sering dilakukan pada anakanak usia prasekolah maupun sekolah setingkat sekolah dasar karena pada usia ini perkembangan penggunaan bahasa meningkat. Menurut Owen (2004) pada periode usia sekolah perkembangan bahasa yang paling jelas adalah perkembangan semantik dan pragmatik, di samping mempelajari bentuk-bentuk baru, anak belajar menggunakan bahasa untuk berkomunikasi dengan lebih efektif. Berdasarkan permasalahan di atas, penulis tertarik untuk melakukan penelitian tentang hubungan pola asuh orang tua dengan kemampuan MLU pada anak usia pra sekolah di Surakarta.

Rumusan masalah dalam penelitian ini adalah: "Adakah hubungan 
antara pola asuh orang tua dengan kemampuan Mean Length of Utterance $(M L U)$ pada anak usia prasekolah di TK ABA Toyibah Surakarta dan TK Sri Juwita Hanum Surakarta.

\section{METODE PENELITIAN}

Penelitian ini dilaksanakan di dua TK yaitu TK ABA Thoyibah dan TK Sri Juwita Hanum Surakarta, pada bulan Maret sampai september 2017. Jenis penelitian ini adalah penelitian kuantitatif dengan rancangan penelitian Deskriptif Korelasional melalui pendekatan Cross Sectional, dalam penelitian ini tidak terdapat intervensi/perlakuan terhadap responden, dan hanya di observasi satu kali saja dan tidak melakukan tindak lanjut.

Populasi pada penelitian ini adalah seluruh anak usia pra sekolah di TK ABA Thoyibah dan TK Sri Juwita Hanum Surakarta, sedangkan teknik sampling dengan menggunakan teknik purposive sampling yang artinya besarnya sampel ditentukan dengan mempertimbangkan tujuan penelitian berdasarkan kriteriakriteria yang ditentukan terlebih dahulu.

Variabel dalam penelitian ini adalah dengan menggunakan Variabel Bebas/ Independen Variable (X) adalah pola asuh orang tua dan Variabel Terikat/Dependent variable (Y) adalah kemampuan Mean Length of Utterance $(M L U)$ atau panjang rata-rata ujaran. Teknik yang digunakan dalam pengumpulan data adalah dengan menggunakan angket berskala likert sebagai alat ukur untuk memperoleh informasi tentang pola asuh orang tua, dan intrumen tes bergambar serta komunikasi interakstif untuk mengukur kemampuan panjang rata-rata ujaran (MLU) pada anak yang sebelumnya telah dilakukan uji validitas dan relabilitas pada instrumen MLU serta studi domumen dengan melihat dan mempelajari dokumendokumen yang terkait dengan penelitian di TK ABA Toyibah Surakarta dan TK Sri Juwita Hanum Surakarta. Hasil uji validitas dan reliabilitas menunjukan bahwa intrumen yang digunakan menunjukan nilai $\mathrm{p}$ value $\leq 0,05$ artinya valid dan hasil uji reliabilitas menjunjukan nilai Alpha Cronbach $\geq 0.60$ artinya reliabel.

Teknik analisis data yang digunakan adalah "Kendal Tau", yang bertujuan untuk mengetahui hubungan antara variabel bebas dan variabel terikat yang berskala data ordinal.

\section{HASIL PENELITIAN}

Penelitain dilakukan di dua TK yaitu TK ABA Thoyiba dan TK Sri Juwita Hanum, total sampel dalam penelitian ini adalah 68 responden dengan karakteristik responden berdasarkan jenis kelamin anak menunjukkan bahwa di TK ABA Thoyibah jumlah responden berjenis kelamin perempuan sebanyak $52.8 \%$ dan laki-laki sebanyak 47,2\%, di TK Sri Juwita hanum jumlah responden kelamin perempuan sebanyak $59,4 \%$ dan laki-laki sebanyak $40,6 \%$.

Sedangkan karakteristik responden berdasrkan usia di TK ABA Thoyibah kelompok terbesar umur anak antara 4 - 5 tahun yaitu sebanyak $66.7 \%$, yang berusia $<4$ tahun sebanyak 19.4\%, dan yang berusia > 5 tahun sebanyak $13.9 \%$. Sedangkan kelompok terbesar umur responden di TK Sri Juwita Hanum yaitu yang berusia > 5 tahun yaitu sebanyak $65.6 \%$, yang berusia antara $4-5$ tahun sebanyak $25.0 \%$, dan yang berusia $<4$ tahun sebanyak $9.4 \%$. 
Karakteristik

responden berdasarkan tingkat pendidik orang tuadi TK ABA Thoyibah pendidikan SLTP sebanyak $7.2 \%$ yang berpendidikan sarjana sebanyak $15.0 \%$, yang berpendidikan Diploma sebanyak 3\% dan yang SLTP sebanyak 2\%. Sedangkan kelompok terbesar tingkat pendidikan orang tua di TK Sri Juwita Hanum adalah sarjana yaitu sebanyak $46.9 \%$, yang berpendidikan SLTA sebanyak $28.1 \%$, yang berpendidikan SLTP sebanyak $18.8 \%$ dan yang berpendidikan Diploma sebayak $6.3 \%$.

Karakteristik

responden berdasarkan pekerjaan orangtua di di TK ABA Thoyibah yang tidak bekerja yaitu sebanyak $58.3 \%$, yang pekerjaanya pegawai swasta sebanyak $30.6 \%$, yang pekerjaanya PNS sebayak $11.1 \%$. Sedangkan pekerjaan orang tua di TK Sri Juwita Hanum adalah pegawai swasta yaitu sebanyak $43.8 \%$, yang tidak bekerja sebanyak $40.6 \%$, dan yang pekerjaanya PNS sebanyak $15.6 \%$.

Karakteristik responden

berdasarkan usia orang tua di TK ABA Thoyibah Surakarta antara 30 - 35 tahun yaitu sebanyak $41.7 \%$, yang berumur $>35$ tahun yaitu sebanyak $36.1 \%$, dan yang berumur $<30$ tahun yaitu sebayak $22.2 \%$. Sedangkan di TK Sri Juwita Hanum Surakarta yang berumur $>35$ tahun yaitu sebanyak $43.8 \%$, yang berumur antara 30 - 35 tahun yaitu sebanyak $28.1 \%$, dan yang berumur $<30$ tahun yaitu sebayak $28.1 \%$.

Hasil analisi univariat dengan Uji statistik deskriptif di TK ABA Thoyibah Surakarta dapat diketahui bahwa rata-rata skor variabel pola asuh orang tua yang terdiri dari demokratis, otoriter, permisif, dan variabel MLU (Mean Length of Utterance) secara berurutan sebagai berikut (Mean \pm SD) adalah (47.00 \pm 6.13$)$, (36.50 \pm 5.73$), \quad(9.00 \pm 1.28), \quad(5.34 \pm 0.72)$ dan total pola asuh orang tua adalah (89.50 \pm 10.04$)$. Hasil Uji statistik deskriptif di TK Sri Juwita Hanum Surakarta dapat diketahui bahwa rata-rata skor variabel pola asuh orang tua yang terdiri dari demokratis, otoriter, permisif, dan variabel MLU (Mean Length of Utterance) secara berurutan sebagai berikut (Mean \pm SD) adalah (44.46 \pm 6.13 ), $(35.50 \pm 4.84), \quad(8.59 \pm 1.16), \quad(5.35 \pm 0.77)$ dan total pola asuh orang tua adalah $(88.56 \pm 9.75)$.

\begin{tabular}{|c|c|c|c|c|c|c|}
\hline \multirow[b]{3}{*}{ Variabel } & \multicolumn{6}{|c|}{$\begin{array}{l}\text { Tabel } 1 \\
\text { Deskriptif Masing-Masing } \\
\text { TK }\end{array}$} \\
\hline & \multicolumn{3}{|c|}{$\begin{array}{l}\text { TK ABA } \\
\text { Thoyibah }\end{array}$} & \multicolumn{3}{|c|}{$\begin{array}{c}\text { TK Sri Juwita } \\
\text { Hanum }\end{array}$} \\
\hline & $\begin{array}{c}\mathrm{Jmlh} \\
(\mathrm{n})\end{array}$ & $\begin{array}{c}\text { Mean } \\
(\mu)\end{array}$ & $\begin{array}{l}\text { Std } \\
\text { Deviasi } \\
(\sigma)\end{array}$ & $\begin{array}{c}\mathrm{Jmlh} \\
(\mathrm{n})\end{array}$ & $\begin{array}{c}\text { Mean } \\
(\mu)\end{array}$ & $\begin{array}{c}\text { Std } \\
\text { Devi } \\
\text { asi } \\
(\sigma)\end{array}$ \\
\hline Pola Asuh & 36 & 89.5 & 10.04 & 32 & 88.56 & 9. \\
\hline $\begin{array}{l}\text { - Demokart } \\
\text { is }\end{array}$ & 36 & $\begin{array}{r}47.0 \\
0\end{array}$ & 6.13 & 32 & 44.46 & $\begin{array}{r}6 . \\
13\end{array}$ \\
\hline - Otoriter & 36 & $\begin{array}{r}36.5 \\
0\end{array}$ & 5.37 & 32 & 35.50 & $\begin{array}{l}4 . \\
84\end{array}$ \\
\hline - Permisif & 36 & 9.00 & 1.28 & 32 & 8.59 & 1. \\
\hline MLU & 36 & 5.34 & 0.72 & 32 & 5.35 & $\begin{array}{r}0 . \\
77\end{array}$ \\
\hline
\end{tabular}

Bentuk pola asuh orang tua di TK ABA Thoyibah Surakarta dan TK Sri Juwita Hanum Surakarta

Tabel 2

Distribusi Frekuensi Bentuk Pola Asuh

\begin{tabular}{llrrrr}
\hline \multirow{2}{*}{ Variabel } & \multirow{2}{*}{ Kategori } & \multicolumn{2}{c}{ TK ABA } & \multicolumn{2}{c}{ TK Sri } \\
\cline { 3 - 6 } & & \multicolumn{2}{c}{ Thoyibah } & \multicolumn{2}{c}{ Juwita H } \\
\cline { 2 - 6 } & & Frek & $(\%)$ & Frek & $(\%)$ \\
\hline Pola asuh & Permisif & 2 & $5.6 \%$ & 1 & 3.1 \\
orang tua & Otoriter & 15 & $41.7 \%$ & 12 & 37.5 \\
& Demokratis & 19 & $52.8 \%$ & 19 & 59.4 \\
\hline & Total & 36 & $100 \%$ & 32 & $100 \%$ \\
\hline
\end{tabular}


Tabel diatas menunjukkan bahwa kelompok terbesar orang tua di TK ABA Thoyibah Surakarta memiliki bentuk pola asuh demokratis yaitu sebanyak 19 responden $(52.8 \%)$, yang memilki pola asuh otoriter sebanyak 15 resonden $(41.7 \%)$ dan yang memilki pola asuh permisif sebanyak 2 resonden (5.6\%). Sedangkan kelompok terbesar orang tua di TK Sri Juwita Hanum Surakarta yang memilki bentuk pola asuh demokratis sebanyak 19 responden (59.4\%), yang memilki pola asuh otoriter sebanyak 12 resonden $37.5 \%$ ) dan yang memilki pola asuh permisif yaitu sebanyak 1 resonden $(3.1 \%)$.

Hasil uji Deskripsi data variabel MLU anak-anak diTK ABA Thoyibah dan TK Sri Juwita Hanum Surakarta menunjukan bahwa anak-anak di TK ABA Thoyibah Surakarta memilki kemampuan MLU tergolong "baik" yaitu sebanyak 16 responden (44.4\%), yang memiliki kemampuan MLU tergolong "sedang" sebanyak 15 resonden $(41.7 \%)$ dan yang memilki kemampuan MLU tergolong "buruk" sebanyak 5 responden (13.9\%). Sedangkan kemampuan MLU anak-anak di TK Sri Juwita Hanum Surakarta yang memilki kemampuan MLU tergolong "baik" yaitu sebanyak 18 responden (56.3\%), yang memiliki kemampuan MLU tergolong "sedang" sebanyak 10 resonden $(31.3 \%)$ dan yang memilki kemampuan MLU tergolong "buruk" yaitu sebanyak 4 resonden $(12.5 \%)$.

Hasil uji bivariat dengan menggunakan Kendall's tau diketahui bahwa uji statistik korelasi dengan menggunakan analisis "Kendall's_tau" pada variabel pola asuh orang tua dengan kemampuan MLU di TK ABA Thoyibah Surakarta diperoleh nilai $p$ value 0.001 , yang berarti nilai $p$ value $0.001 \leq 0.05$, hal ini menunjukan ada hubunganyang signifikanantara pola asuh orang tua dengan kemampuan MLU di TK ABA Thoyibah Surakarta, Adapun arah korelasi dapat dilihat dari nilai rhitung 0.389 yang berarti ada korelasi yang positif antara Pola asuh orang tua dengan kemampuan MLU di TK ABA Thoyibah Surakarta. Sedangkan kekuatan hubungan dapat dilihat dari hasil nilai rhitung 0.389, yang menunjukan kekuatan korelasi termasuk "lemah" karena termasuk diantara 0.20-0.399.

Tabel 3

Analisis Bivariat Pola Asuh Di TK ABA Thoyibah Surakarta

Correlations TK ABA Thoyibah Surakarta

\begin{tabular}{|c|c|c|c|c|}
\hline \multirow{2}{*}{$\begin{array}{l}\text { Kendall's } \\
\text { tau_b }\end{array}$} & \multirow[b]{2}{*}{$\begin{array}{l}\text { pola_ } \\
\text { asuh }\end{array}$} & \multicolumn{2}{|c|}{ pola_asuh } & MLU \\
\hline & & $\begin{array}{l}\text { Correlation } \\
\text { Coefficient }\end{array}$ & 1.000 & $.389^{* *}$ \\
\hline & & $\begin{array}{l}\text { Sig. (2- } \\
\text { tailed) }\end{array}$ & . & .001 \\
\hline & & $\mathrm{N}$ & 36 & 36 \\
\hline & MLU & $\begin{array}{l}\text { Correlation } \\
\text { Coefficient }\end{array}$ & $.389^{* *}$ & 1.000 \\
\hline & & $\begin{array}{l}\text { Sig. (2- } \\
\text { tailed) }\end{array}$ & .001 & . \\
\hline & & $\mathrm{N}$ & 36 & 36 \\
\hline
\end{tabular}

Hasil uji bivariat di TK Sri Juwita Hanum, menunjukan bahwa uji statistik korelasi dengan menggunakan analisis "Kendall's tau" pada variabel pola asuh orang tua dengan kemampuan MLU di TK Sri Juwita Hanum Surakarta diperoleh nilai $p$ value 0.004 , yang berarti nilai $p$ value $0.004 \leq 0.05$, hal ini menunjukan $a d a$ hubunganyang signifikan antara pola asuh orang tua dengan kemampuan MLU di TK Sri Juwita Hanum Surakarta, Adapun arah korelasi dapat dilihat dari nilai rhitung 0.373 yang berarti ada korelasi yang positif antara 
Pola asuh orang tua dengan kemampuan MLU di TK Sri Juwita Hanum Surakarta. Sedangkan kekuatan hubungan dapat dilihat dari hasil nilai rhitung 0.373, yang menunjukan kekuatan korelasi termasuk "lemah" karena termasuk diantara 0.200.399 .

\section{Tabel 4}

\section{Analisis Bivariat Pola Asuh Di TK Sri} Juwita Hanum Surakarta

\begin{tabular}{|c|c|c|c|c|}
\hline \multicolumn{5}{|c|}{ Correlations TK Sri Juwita Hanum } \\
\hline & & & pola_asuh & MLU \\
\hline \multirow[t]{6}{*}{$\begin{array}{l}\text { Kendall's } \\
\text { tau_b }\end{array}$} & $\begin{array}{l}\text { pola_- } \\
\text { asuh }\end{array}$ & $\begin{array}{l}\text { Correlation } \\
\text { Coefficient }\end{array}$ & 1.000 & $.373^{* *}$ \\
\hline & & $\begin{array}{l}\text { Sig. (2- } \\
\text { tailed) }\end{array}$ & & .004 \\
\hline & & $\mathrm{N}$ & 32 & 32 \\
\hline & MLU & $\begin{array}{l}\text { Correlation } \\
\text { Coefficient }\end{array}$ & $.373^{* *}$ & 1.000 \\
\hline & & $\begin{array}{l}\text { Sig. (2- } \\
\text { tailed) }\end{array}$ & .004 & . \\
\hline & & $\mathrm{N}$ & 32 & 32 \\
\hline
\end{tabular}

\section{PEMBAHASAN} $\begin{array}{lll}\text { Dari hasil uji statistik korelasi } & \\ \text { dengan } & \text { menggunakan } & \text { analisis }\end{array}$ "Kendall's_tau" pada variabel pola asuh orang tua dengan kemampuan MLU di TK ABA Thoyibah Surakarta dilihat dari nilai $p$ value 0.001 , yang berarti nilai $p$ value 0.001 $\leq 0.05$, hal ini menunjukan ada hubungan yang signifikan antara pola asuh orang tua dengan kemampuan MLU di TK ABA Thoyibah Surakarta. Adapun arahkorelasi dapat dilihat dari nilai rhitung 0.389 yang berarti ada korelasi yang positif antara Pola asuh orang tua dengan kemampuan MLU di TK ABA Thoyibah Surakarta. Sedangkan kekuatan hubungan dapat dilihat dari hasil nilai rhitung 0.389, yang menunjukan kekuatan korelasi termasuk "lemah" karena termasuk diantara 0.200.399 . $\begin{array}{lll}\text { Dari hasil uji statistik } & \text { korelasi } \\ \text { dengan } & \text { menggunakan } & \text { analisis }\end{array}$ "Kendall's_tau" pada variabel pola asuh orang tua dengan kemampuan MLU di TK Sri Juwita Hanum Surakarta diperoleh nilai $p$ value 0.004 , yang berarti nilai $p$ value $0.004 \leq 0.05$, hal ini menunjukan ada hubungan yang signifikan antara pola asuh orang tua dengan kemampuan MLU di TK Sri Juwita Hanum Surakarta. Adapun arahkorelasi dapat dilihat dari nilai rhitung 0.373 yang berarti ada korelasi yang positif antara Pola asuh orang tua dengan kemampuan MLU di TK Sri Juwita Hanum Surakarta. Sedangkan kekuatan hubungan dapat dilihat dari hasil nilai rhitung 0.373 , yang menunjukan kekuatan korelasi termasuk "lemah" karena termasuk diantara 0.20-0.399.

Dari hasil uji statistik korelasi dengan menggunakan analisis "Kendall's_tau" pada variabel pola asuh orang tua dengan kemampuan MLU di kedua TK yaitu TK ABA Thoyibah dan TK Sri Juwita Hanum Surakarta diperoleh nilai $p$ value 0.000 , yang berarti nilai $p$ value $0.000 \leq 0.05$, hal ini menunjukan ada hubungan yang signifikan antara pola asuh orang tua dengan kemampuan MLU di TK ABA Thoyibah dan TK Sri Juwita Hanum Surakarta. Adapun arah korelasi dapat dilihat dari nilai rhitung 0.364 yang berarti ada korelasi yang positif antara Pola asuh orang tua dengan kemampuan MLU di TK Sri Juwita Hanum Surakarta. Sedangkan kekuatan hubungan dapat dilihat dari hasil nilai rhitung 0.364, yang menunjukan kekuatan korelasi termasuk "lemah" karena termasuk diantara 0.20-0.399.

Tingginya penerapan pola asuh demokratis oleh orangtua anak di TK ABA Thoyibah Surakarta ini diketahui berdasarkan hasil penyebaran kuesioner tentang pola asuh yang sengaja dibagikan 
untuk mengetahui bentuk penerapan pola asuh orang tua di sekolah ini. Koesioner pola asuh yang disusun berdasarkan aspek aspek pola asuh demokratis yang terdiri dari peraturan, hukuman, penghargaan, dan konsistensi menunjukkan bahwa para orangtua sudah menyadari pentingnya pengasuhan yang baik dan berkualitas untuk anak.

Jadi penelitian ini membuktikan bahwa anak yang dididik dengan pola asuh demokratis akan memiliki dampak positif untuk perkembangan dan kepribadian anak, sehingga akan memacu anak untuk lebih berprestasi, seperti yang dikemukakan oleh Bety Bea Septiari (2012) dalam Lestari (2013) bahwa pola asuh demokratis yang ditandai dengan pengakuan orang tua terhadap kemampuan anak dan anak diberi kesempatan untuk tidak selalu bergantung pada orang tua akan membuat anak lebih mandiri, percaya diri, mempunyai kontrol diri, mempunyai minat terhadap hal-hal baru, patuh dan berorientasi pada prestasi. Berbeda dengan anak yang dididik dengan pola asuh permisif, sehingga anak akan cenderung agresif, tidak patuh, kurang mampu mengontrol diri dan kurang memikirkan masa depannya. Hal ini senada dengan pendapat Beumrind yang dikutip Diane E. Papalia (2009) bahwa anak yang dididik dengan pola asuh demokratis akan cenderung mengandalkan diri, dapat mengotrol diri, lebih asertif, mengeksplorasi dan merasa aman. Sedangkan anak yang dididik dengan pola asuh permisif akan cenderung belum matang, tidak memiliki kontrol diri dan tidak terlalu suka bereksplorasi.

Orang tua selalu mempunyai pengaruh yang paling kuat pada anak. Setiap orang tua mempunyai pola asuh tersendiri dari segi asuh, asah, dan asih dalam hubungannya dengan anakanaknya, dan ini mempengaruhi perkembangan anak (Djiwandono,2003 dalam Fatimah). Keluarga merupakan lingkungan sosial pertama dan utama bagi anak sehingga memberi pengaruh terbesar bagi perkembangan anak. Keluarga terutama ayah dan ibu memberikan dasar pembentukan tingkah laku, watak, moral dan pendidikan anak. Pengalaman interaksi di dalam keluarga akan menentukan pola dan tingkah laku anak terhadap orang lain dalam masyarakat (Soetjiningsih, 2002).

Pola asuh orang tua yang baik dengan selalu mengepresikan kasih sayang (memeluk, mencium, memberi pujian), melatih emosi dan melakukan pengontrolan pada anak akan berakibat anak merasa diperhatikan dan akan lebih percaya diri, sehingga hal ini akan membentuk pribadi anak yang baik. Hal ini akan sangat berpengaruh terhadap perkembangan anak sejak dini yang meliputi perkembangan personal sosial, bahasa, motorik halus dan motorik kasar. Anak yang merasa diperhatikan dan disayangi oleh orang tuanya tidak ada rasa takut untuk bergaul dengan orang lain, anak lebih berekspresif, kreatif, tidak takut untuk mencoba hal-hal baru sehingga perkembangan anak terutama anak-anak di bawah 5 tahun akan maksimal.

Hal ini menunjukkan bahwa tinggi rendahnya prestasi belajar siswa sangat bergantung pada pola asuh yang diterapkan oleh orang tua di rumah. Hasil penelitian ini memperkuat penelitian yang pernah dilakukan sebelumnya oleh Yusniyah (2008) yang dikutip oleh Lestari dkk (2009) bahwa penerapan pola asuh demokratis dinyakini dan terbukti dapat meningkatkan prestasi belajar siswa, 
karena dengan penerapan pola asuh demokratis akan membantu siswa tumbuh dengan baik, sehingga dapat memacu prestasi belajarnya.

Keterampilan berbicara anak-anak TK di Surakarta yang tinggi ini diduga karena adanya hubungan yang positif dari pola asuh demokratis yang diterapkan oleh orangtua. Santrock (2007) dalam Marlina (2015) menyebutkan bahwa ada dua aspek yang melatarbelakangi proses perkembangan berbicara seseorang. Kedua aspek tersebut yaitu aspek biologis atau nature dan aspek lingkungan atau nurture. Keluarga khususnya orangtua merupakan lingkungan yang pertama dan utama bagi anak. Anak akan belajar tentang banyak hal pertama kali dari orangtuanya, termasuk belajar berbicara. Orang tua mempunyai peran yang sangat besar dalam proses keterampilan berbicara anak. Hal ini sesuai dengan penelitian yang dilakukan oleh Lemonda dan Rodrigues (2009) dalam Marlina (2015) yang menyatakan bahwa terdapat tiga aspek keluarga yang telah ditandai sebagai dasar pemerolehan bahasa awal dan pembelajaran anak-anak. Ketiga aspek tersebut meliputi frekuensi partisipasi anak dalam kegiatan belajar rutin (misalnya, membaca buku bersama, mendongeng), kualitas pengasuhan dan keterlibatan anak (misalnya, stimulasi kognitif dan sensivitas/respon dari orangtua), dan penyediaan fasilitas yang sesuai dengan usia anak (misalnya, buku dan mainan).

Hasil penelitian juga menunjukkan bahwa siswa yang dididik dengan pola asuh demokratis memiliki kemampuan berbicara yang lebih baik dalam hal ini tentang panjang rata-rata ujaran pada anak dibandingkan dengan pola asuh permisif atau pola asuh otoriter. Hasil ini sesuai dengan pendapat Ngalim Purwanto (2007), dimana dukungan, suasana dan keadaan keluarga turut menentukan prestasi belajar anak. Hasil penelitian juga sesuai dengan penelitian yang pernah dilakukan Yusniyah (2008) bahwa ada hubungan antara pola asuh orang tua dengan prestasi belajar siswa, dan penerapan pola asuh demokratis dapat meningkatkan prestasi belajar siswa, karena dengan penerapan pola asuh demokratis dapat membantu siswa tumbuh dengan baik sehingga dapat memacu prestasi belajarnya..

\section{KESIMPULAN DAN SARAN}

Berdasarkan hasil analisis dan pembahasan tentang "Hubungan pola asuh orang tua dengan kemampuan MLU (Mean Length of Utterance) di TK ABA Thoyibah Surakarta dan TK Sri Juwita Hanum Surakarta", maka dapat ditarik kesimpulan sebagai berikut:

1. Pola asuh yang diterapkan orang tua pada anaknyadi TK ABA Thoyibah Surakarta kategori pola asuh "demokratis" sebanyak 19 responden $(52.8 \%)$, kategori pola asuh "otoriter" sebanyak 15responden (41.7\%) dankategori pola asuh "permisif" sebanyak 2 responden (5.6\%). Sedangkan pola asuh yang diterapkan orang tua pada anaknyadi TK Sri Juwita Hanum Surakarta kategori pola asuh "demokratis" sebanyak 19 responden (59.4\%), kategori pola asuh "otoriter" sebanyak 12responden $(37.5 \%)$ dankategori pola asuh "permisif" sebanyak 1 responden $(3.1 \%)$.

2. Kemampuan MLU (Mean Length of Utterance) pada anak-anak di TK ABA Thoyibah Surakarta memilki kemampuan MLU tergolong "baik" 
yaitu sebanyak 16 responden (44.4\%), yang memiliki kemampuan MLU tergolong "sedang" sebanyak 15 resonden $(41.7 \%)$ dan yang memilki kemampuan MLU tergolong "buruk" sebanyak 5 responden (13.9\%). Sedangkan kemampuan MLU anakanak di TK Sri Juwita Hanum Surakarta yang memilki kemampuan MLU tergolong "baik" yaitu sebanyak 18 responden (56.3\%), yang memiliki kemampuan MLU tergolong "sedang" sebanyak 10 resonden (31.3\%) dan yang memilki kemampuan MLU tergolong "buruk" yaitu sebanyak 4 resonden (12.5\%).

3. Hubungan antara pola asuh orang tua dengan kemampuan MLU di TK ABA Thoyibah Surakarta dapat dilihat dari hasil uji statistik korelasi dengan menggunakan analisis "Kendall's_tau"maka diperoleh nilai $p$ value $0.001 \leq 0.05$, hal ini menunjukan ada hubunganyang signifikanantara pola asuh orang tua dengan kemampuan MLU di TK ABA Thoyibah Surakarta, Adapun arah korelasi dapat dilihat dari nilai rhitung 0.389 yang berarti ada korelasi yang positif. Sedangkan kekuatan hubungan termasuk “lemah"karena termasuk diantara 0.20-0.399.

4. Hubungan antara pola asuh orang tua dengan kemampuan MLU di TK Sri Juwita Hanum Surakarta dapat dilihat dari hasil uji statistik korelasi dengan menggunakan analisis "Kendall's tau"maka diperoleh nilai $p$ value $0.004 \leq 0.05$, hal ini menunjukan ada hubunganyang signifikan antara pola asuh orang tua dengan kemampuan MLU di TK Sri Juwita Hanum Surakarta, Adapun arah korelasi dapat dilihat dari nilai rhitung0.373 yang berarti ada korelasi yang positif, Sedangkan kekuatan hubungan termasuk “lemah"'karenatermasuk diantara 0.200.399.

5. Hubungan antara pola asuh orang tua dengan kemampuan MLU di TK ABA Thoyibah Surakarta dan TK Sri Juwita Hanum dapat dillihat dari hasil uji statistik korelasi dengan menggunakan analisis "Kendall's_tau"maka diperoleh nilai $p$ value $0.000 \leq 0.05$, hal ini menunjukan ada hubungan yang signifikan antara pola asuh orang tua dengan kemampuan MLU di TK ABA Thoyibah dan TK Sri Juwita Hanum Surakarta, adapun arah korelasi dapat dilihat dari nilai rhitung 0.364 yang berarti ada korelasi yang positif, sedangkan kekuatan hubungan termasuk "lemah"karenatermasuk diantara 0.20-0.399.

Berdasarkan hasil penelitian dan kesimpulan yang telah diuraikan di atas maka dapat diberikan beberapa saran sebagai berikut:

1. Bagi orang tua siswa, Diharapkan orang tua menerapkan pola asuh demokratis dalam mendidik anakanaknya karena pola asuh demokratis dinyakini dan terbukti dapat meningkatkan kemampuan MLU atau panjang rata-rata ujaran anak. Penerapan pola asuh demokratis akan membantu anak tumbuh dengan baik, sehingga dapat memacu perkembangan bicara anak, karena orang tua selalu mengajak anak anakanaknya untuk berkomunikasi dan berinteraksi dengan orang tua.

2. Bagi guru/pendidik, TK ABA Thoyibah Surakarta dan TK Sri Juwita Hanum Surakarta, handakya 
dapat memberikan informasi kepada orang tua terkait pola asuh yang tepat sehingga memacu perkembangan bahasa dan bicara anak.

3. Bagi peneliti selanjutnya, disarankan agar menggunakan metode lain dalam pengambilan data pada orang tua ketika meneliti pola asuh orang tua misalnya melalui wawancara mendalam terhadap siswa dan orang tuanya meskipun hanya sebagian saja, sehingga informasi yang diperoleh dapat bervariasi dan lebih kuat daripada menggunakan sistem angket/ kuesioner.

\section{DAFTAR RUJUKAN}

Brown, R (1973) A First Language: The Early Stages. Harvard University Press. ISBN 0-674-30326-1

Diane E Papalia. 2009. Human Development/Perkembangan Manusia. Jakarta: Penerbit Salemba Humanika

Euis, S., 2004. Mengasuh Anak dengan Hati. Jakarta: PT Elex Media Komputindo.

Fatimah , 2012, Hubungan Pola Asuh Orang Tua dengan Perkembangan Anak di R.A Darussalam Desa Sumber Mulyo, Jogoroto, Jombang,

Lestari dkk 2009, Hubungan Antara Pola Asuh Orang Tua Dengan Prestasi Belajar Siswa Konsentrasi Patiseri SMK Negeri 1 Sewon Bantul

Maccoby, E E., 1980. Social Development Psychological Growth and Parent Child Relationship. New York: HB Javanovich.

Marlina 2015,Hubungan Pola Asuh Demokratis Dengan Keterampilan Berbicara Anak Tk Kelompok B
Ngalim Purwanto. 2007. Psikologi Pendidikan. Bandung: Penerbit Remaja Rosdakarya

Owen R.E, 2004. Language Disorders: a Functions Approach to Assesment and Intervention. New York: Pearson Education.

Santrock, J. W., 2002. Life Span Development: Perkembangan Masa Hidup. Edisi 5. Alih bahasa: Juda Damantik dan Achmad Chusairi. Jakarta: Penerbit Erlangga

Santrock, J. W., 2007. Perkembangan Anak. Ed.11. Jilid 1. Jakarta: Erlangga

Soetjiningsih, 2002. Tumbuh Kembang anak. EGC : Jakarta

Stewart \& Koch, 1983. Chidren Development Throught Adolescence. Canada: John Wiley and Sons, Inc.

Yusniyah. 2008. Skripsi. Hubungan Pola Asuh Orang Tua dengan Prestasi Belajar Siswa MTS Al-Falah. Jakarta Timur.Universitas Islam Negeri Syarif Hidayatullah Jakarta. 